\section{Domestic Violence Against Children and Adolescents: Prevalence of Physical Injuries in a Southern Brazilian Metropolis}

Graduate Program in Dentistry,

Positivo University, Curitiba, PR, Brazil

Correspondence: Dra. Estela

Maris Losso, Rua Pedro Viriato

Parigot de Souza, 5300 Campo

Comprido, 81280-330 Curitiba, PR,

Brazil. Tel: +55-41-3336-5962.

email: lossoem@gmail.com
Leidielly Aline Valente, Mariana Dalledone, Eduardo Pizzatto, Wellington

Zaiter, Juliana Feltrin de Souza, Estela Maris Losso

\begin{abstract}
Violence against children and adolescents is a public health issue worldwide that threatens physical and mental wellbeing and causes irreparable harm. Reports on this violence are an essential way to prevent it and to protect the children and adolescents. Thus, the objective of the present study was to evaluate the prevalence of physical injuries that occur in domestic environments and reported to the Child and Adolescent Protection Network. This retrospective study was conducted at the Epidemiology Center of the Municipality of Curitiba. A total of 10,483 reports for the years $2010(5,112)$ and 2011 $(5,371)$ were analyzed and from them were selected reports of physical injuries that occurred in the family environment. The children and adolescents were 0-17 years old, comprising 322 cases of physical abuse within the family in 2010 . Out of these, $57.1 \%$ were male and $42.9 \%$ were female, and $58 \%$ (187) presented head and neck injuries. There were 342 reports in 2011, 49\% were male and 51\% were female; head and neck injuries corresponded to 65\% (222) of the reported cases. The prevalence of injuries increased by $6 \%$ and head and neck injury increased by 19\% between 2010 and 2011 . It may be concluded that physical abuse is associated with a high prevalence of head and neck injury, which is easily observed by the health and education professionals. Notification organs should be created in Brazilian hospitals and health centers, which is essential to conduct epidemiological surveillance and appropriate policies.
\end{abstract}

Key Words: domestic violence, facial injuries, neck injuries, child.

\section{Introduction}

Violence against children and adolescents is a major public health issue worldwide that threatens physical and mental wellbeing and causes irreparable harm. This is a complex phenomenon that is triggered by multiple factors, including social, political, economic and cultural issues (1). In Brazil, 107,572 cases of child abuse were recorded in 2011 (2).

According to the Brazilian Ministry of Health (3), child abuse is any action or omission that prejudices the physical and psychological wellbeing, freedom, and right to full development of children. Abuse can be classified as physical, sexual or psychological abuse or neglect.

Physical violence can be classified as mild (e.g., bruises and a few abrasions), moderate (e.g., more severe bruises, burns and simple fractures) and severe (e.g., large burns and multiple fractures that can threaten life). Physical injuries can be noticed by professionals in the health field like several clinical manifestations on the skin and mucosa (principally the face, lips, buttocks, arms and back), oral lesions and dental trauma, among others (4-7). The most common injuries are bruises, abrasions, ecchymosis, and hematomas. Some lesions may reproduce the shape of the offending object, such as burns from cigarette butts (4-7).
In Curitiba city in the Paraná state, Brazil, the Child and Adolescent Protection Network is a public institution that is responsible for reports of violence against children and adolescents. A gradual increase was observed in the number of reports between 2003 and 2007 (8). Since 2008, the increase has been more than 5,000 reports per year. Data from 2004 to 2008 indicated that domestic violence was involved in 88-91.9\% of the child and adolescent cases reported to the Child and Adolescent Protection Network. Neglect and physical violence comprised more than $80 \%$ of the suspected or confirmed cases of child maltreatment (9).

In 2010, 5,112 suspected or confirmed cases of violence against children and adolescents were reported in Curitiba. Among these, $84.7 \%$ were characterized as intrafamilial, among them $73 \%$ were cases of neglect and $13.3 \%$ were cases of physical aggression (8). In 2011, 5,371 suspected or confirmed cases were reported. Among these, $81.8 \%$ were intrafamilial, of which $74.8 \%$ were cases of neglect and $12.1 \%$ were cases of physical aggression (10). In these 2 years, more than $50 \%$ of the victimized children were 5 to 14 years old.

Intrafamilial or domestic violence is violence perpetrated by any family member on another family member. In domestic violence, one of the child's or adolescent's parents 
is generally the abuser, and the other parent maintains a passive posture, thus allowing the abuse to occur and continue (11-13).

A study performed in Brazil evaluated the prevalence of physical abuse and the severity of parental violence against children, according to region. The prevalence of physical violence was $44.1 \%$, of which $33.8 \%$ was moderate and $10.3 \%$ was severe. The Center-West (25.9\%) and South $(23.9 \%)$ regions presented the highest levels of severe parental violence (14).

Any health professional can identify aggression against children. Approximately 50-75\% of the physical lesions in cases of child maltreatment occur on the head, neck, face and mouth, which can be easily seen (15-17). Naidoo (17) reported that $67 \%$ of 300 cases of physical lesions occurred on the head, face, neck and mouth. Eleven percent of the lesions occurred in the oral cavity. Among the injuries to the upper part of the body, $41 \%$ were located on the victim's face, with several orofacial injuries, including skull fracture, subdural hematomas, retinal hemorrhage, bruises, burns and lacerations. In the mouth, the reported injuries included fractured teeth, avulsed teeth, jaw fractures, and lacerations of the lips, frenulum and tongue. In the upper body, $82 \%$ of the cases involved single lesions, and 18\% involved multiple lesions. Among the multiple lesions in the upper body, 96\% were on the face. The frequency of injuries to the lower body (i.e., below the neck) was 31\%. Among these injuries, 58\% presented a single lesion, and $42 \%$ presented multiple lesions. Among the cases of multiple lesions, the children had an average of two lesions. The most common lesions were hematomas.

A study performed in Brazil evaluated 1,070 reports of cases of children and adolescents who suffered maltreatment that were registered at the Department of Forensic Medicine of Paraiba. The study found that $56.3 \%$ of the victims sustained injuries to the head and neck, $41 \%$ of the injuries were on the face, $55.6 \%$ of the injuries affected the jaw, and $94.8 \%$ of the cases presented lacerations of soft tissue (11).

Because of the importance of this subject, knowledge of the prevalence of physical reported injuries, types of injuries, aggressors and reporting institutions, it is important to conduct action and public health policies to prevent maltreatment and protect children and adolescents. Therefore, the objective of the present study was to evaluate the prevalence of physical injuries that occur in domestic environments and reported to the Child and Adolescent Protection Network.

\section{Material and Methods}

This retrospective study was conducted after approval by the Ethics Committee of Positivo University (Protocol no. 111/2010) and Committee of Ethics in Research of the Curitiba. The data were collected in the Epidemiology Center of the Municipality of Curitiba of the Child and Adolescent Protection Network. Out of a total of 10,483 cases, 5,112 were reported in 2010 and 5,371 were reported in 2011. To compose the study sample were selected cases of intrafamilial physical violence reported in Curitiba city and the metropolitan region involving children aged 0 to 17 years. The cases were reported by education, health and social assistance institutions.

The Child and Adolescent Protection Network cooperate with several notification units where professionals are able to identify signs of violence and submit the mandatory report. The mandatory notification form has data related to victim identification and profile, a description of the incident, the frequency of violence, the nature of violence (e.g., neglect, physical, psychological), the type of violence (intrafamilial, extrafamilial, domestic self-aggression, fetal, or ignored), the aggressor, presence of apparent injury, type of injury and the part of the body that was involved.

Data were collected from reports that had information about the victim (age, sex, frequency of violence), reporting unit (education, health and social assistance), and aggressor. The data were analyzed statistically using SPSS Statistic 20.0 (IBM, Armonk, NY, USA). Chi-square test was used to compare frequencies between the variables. The significance level was set at $p<0.05$.

\section{Results}

A total of 964 cases of intrafamilial physical abuse were compiled. Among them, were analyzed cases of intrafamilial physical abuse and found that $65.18 \%$ (322) and $72.76 \%$ (342) of the cases in 2010 and 2011, respectively, involved apparent physical injury at the time of the report. Table 1 shows the notifications in 2010 and 2011 according to the children's age and sex. Of the 322 reports of physical injury in 2010, 57.1\% (184) involved male victims, and 42.9\% (138) involved female victims. Out of the 342 reports on physical injury in 2011, 51\% (175) involved female victims, and 49\% (167) involved male victims. Table 2 presents the frequency of reports according to the age group.

The analysis of the reports according to the frequency of violence in 2010 and 2011, shows that $32.9 \%$ and $34.7 \%$ of the cases were the first report of violence and 29.8\% and $30.4 \%$ of the cases were reports of chronic violence, respectively. Regarding the age groups, they were similar with regards to the frequency of first-time notifications, followed by chronic violence for which an increased frequency was observed in children older than 5 years (Table 2). Statistically significant difference was found in the frequency of violence according to age group ( $p=0.007)$.

Considering the notification units, such as health, 
education and social assistance units, Education units were responsible for $50.6 \%$ of the notifications, followed by health units $(37.2 \%)$ and social assistance institutions $(13.4 \%)$

Table 3 shows a comparison between 2010 and 2011 with regard to the most frequent head and neck injuries

Table 1. Prevalence of physical injuries in 2010 and 2011 according to age and sex, Curitiba, PR, Brazil

\begin{tabular}{|c|c|c|c|}
\hline \multirow{2}{*}{\multicolumn{2}{|c|}{ Victims Frequency (\%) }} & 2010 & 2011 \\
\hline & & \multicolumn{2}{|l|}{ Frequency (\%) } \\
\hline \multirow{3}{*}{ Age } & $0-4$ years & $74(23.5)$ & $90(26.5 \%)$ \\
\hline & 5-10 years & $148(47.0 \%)$ & $136(40.1 \%)$ \\
\hline & $11-17$ years & $93(29.5 \%)$ & $113(33.3 \%)$ \\
\hline \multicolumn{2}{|l|}{ Total } & $315(100 \%)$ & $339(100 \%)$ \\
\hline \multirow{2}{*}{ Sex } & Female & $138(42.9 \%)$ & $175(51.0 \%)$ \\
\hline & Male & $184(57.1 \%)$ & $167(49.0 \%)$ \\
\hline \multicolumn{2}{|l|}{ Total } & $322(100 \%)$ & $342(100 \%)$ \\
\hline
\end{tabular}

No statistically significant differences were found between sexes $(p=0.23)$ or between age groups $(p=0.20)$. Chi-square test.

Table 2. Frequency of reports in 2010 and 2011, Curitiba, PR, Brazil

\begin{tabular}{|c|c|c|c|c|c|}
\hline \multirow{2}{*}{$\begin{array}{l}\text { Age } \\
\text { group }\end{array}$} & \multicolumn{4}{|c|}{ Frequency of violence } & \multirow{2}{*}{ Total } \\
\hline & First time & Occasional & Chronic & lgnored & \\
\hline \multirow{2}{*}{$\begin{array}{l}0-4 \\
\text { years }\end{array}$} & 58 & 38 & 35 & 31 & 162 \\
\hline & $35.8 \%$ & $23.5 \%$ & $21.6 \%$ & $19.1 \%$ & $100.0 \%$ \\
\hline \multirow{2}{*}{$\begin{array}{l}5-10 \\
\text { years }\end{array}$} & 100 & 37 & 84 & 60 & 281 \\
\hline & $35.6 \%$ & $13.2 \%$ & $29.9 \%$ & $21.4 \%$ & $100.0 \%$ \\
\hline \multirow{2}{*}{$\begin{array}{l}11-17 \\
\text { years }\end{array}$} & 63 & 29 & 78 & 35 & 205 \\
\hline & $30.7 \%$ & $14.1 \%$ & $38.0 \%$ & $17.1 \%$ & $100.0 \%$ \\
\hline \multirow{2}{*}{ Total } & 221 & 104 & 197 & 126 & 648 \\
\hline & $34.1 \%$ & $16.0 \%$ & $30.4 \%$ & $19.4 \%$ & $100.0 \%$ \\
\hline
\end{tabular}

Statistically significant differences were found between age groups and frequency of the violence $(p=0.007)$. Chi-square test. among the victims and the most frequent injuries to the whole body. Hematomas and lacerations were the most frequent injuries in the 2-year-old group.

A significant difference in aggressors was observed $(p=0.009)$. The mother was the principal aggressor in $45.62 \%$ of the cases, followed by the father $(24.47 \%)$ and spouses (16.96\%) in 2010 and 2011 (Table 4).

Figure 1 shows the prevalence of physical injuries to the head, neck, and mouth in 2010 and 2011. Most of the injuries occurred on the head in both sexes. Figure 2 illustrates the frequency of physical injuries to the body (except head and neck) in children in 2010. The upper and lower limbs presented most of the lesions. Figure 3 shows the frequency of physical injuries to the body (except head and neck) in 2011. Again, the upper and lower limbs presented most of the lesions. An 18.7\% increase was observed in the prevalence of notifications of physical abuse, from 5.1\% in 2010 to $6.2 \%$ in 2011.

Table 3. Most frequent injuries on the head, neck and entire body in 2010 and 2011 (2010: $n=186 ; 2011: n=229$ ), Curitiba, PR, Brazil

\begin{tabular}{lcc}
\hline $\begin{array}{l}\text { lnjuries on the } \\
\text { head and neck }\end{array}$ & 2010 & 2011 \\
\cline { 2 - 3 } Hematomas & $\%(\mathrm{n})$ & $\%(\mathrm{n})$ \\
Cuts & $21.5 \%(40)$ & $14.0 \%(32)$ \\
Burns & $5.9 \%(11)$ & $6.6 \%(15)$ \\
Scratches & $4.3 \%(08)$ & $3.9 \%(09)$ \\
Other injuries & $8.1 \%(15)$ & $18.3 \%(42)$ \\
Total & $100 \%(186)$ & $100 \%(229)$ \\
Lesions on the body & $\%(\mathrm{n})$ & $\%(\mathrm{n})$ \\
Hematomas & $73.2 \%(254)$ & $73.5 \%(244)$ \\
Cuts & $8.1 \%(28)$ & $5.7 \%(19)$ \\
Burns & $5.8 \%(20)$ & $10.2 \%(34)$ \\
Scratches & $13.0 \%(45)$ & $10.5 \%(35)$ \\
Total & $100 \%(347)$ & $100 \%(332)$ \\
\hline
\end{tabular}

No statistically significant differences were found between the lesions in head and neck $(p=0.44)$ and on the body $(p=0.59)$. Chi-square test.

Table 4. Frequency of aggressors in 2010 and 2011, Curitiba, PR, Brazil

\begin{tabular}{ccccccccc}
\hline \multirow{2}{*}{ Year } & \multicolumn{7}{c}{ Aggressor } \\
\cline { 2 - 6 } & Mother \% (n) & Father \% (n) & Grandparent \% (n) & Spouse \% (n) & Uncle \% (n) & Babysitter \% (n) & Brother \% (n) \\
\hline 2010 & $46.6(150)$ & $27.0(87)$ & $2.5(8)$ & $15.8(51)$ & $4.0(13)$ & $0(0)$ & $4.0(13)$ & $100(322)$ \\
2011 & $44.4(152)$ & $21.9(75)$ & $2.3(8)$ & $17.8(61)$ & $3.8(13)$ & $0.9(3)$ & $8.2(28)$ & $100(340)$ \\
Total & $100(302)$ & $100(162)$ & $100(16)$ & $100(112)$ & $100(26)$ & $100(3)$ & $100(41)$ & $100(662)$ \\
\hline
\end{tabular}

Statistically significant differences were found between the aggressors $(p=0.009)$. Chi-square test. 


\section{Discussion}

Health professionals play an important role in perceiving and diagnosing physical abuse in children and adolescents and to report suspicious cases to reduce recidivism and prevent such situations from becoming chronic, which may eventually lead to death. By the notification, the responsible agencies are informed about the profile of physical abuse, which is essential to guide actions and public health policies that aid prevention and support the health of children and adolescents. In the present study, 30\% of the reported cases in 2010 and 2011 involved chronic abuse, which greatly affects the child's entire life, possibly into adulthood, and these abused children may even become abusers of their own children (8).

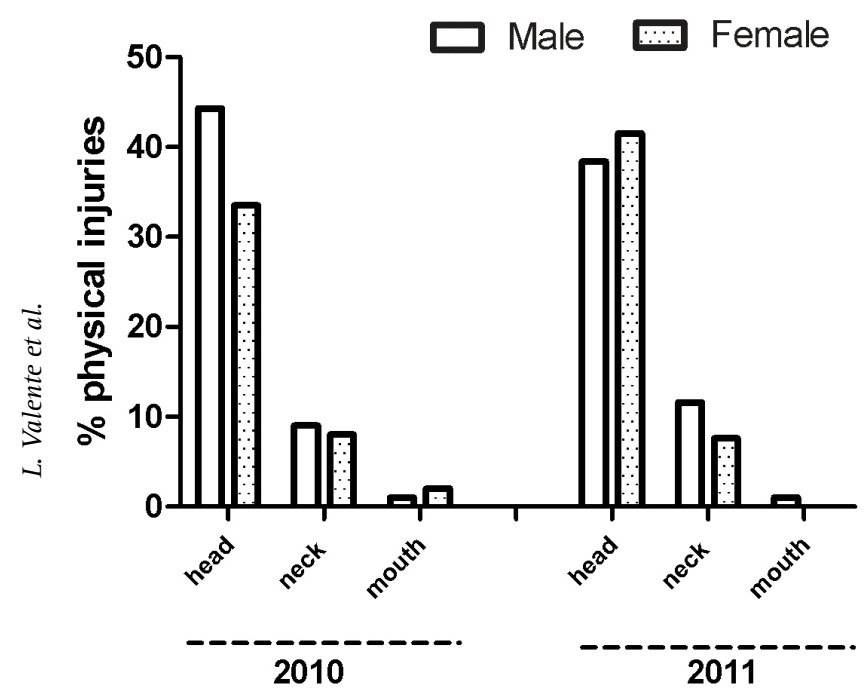

Figure 1. Head and neck injuries reported in $2010(n=187)$ and 2011 $(n=222)$ according to sex.
An increase was observed in the number of reports of violence from 2003 to 2008, with approximately 5,000 notifications per year until 2011. A disturbing fact is that violence often occurs in the family environment, which should be a place of protection for children and adolescents (8). An increase in the prevalence of head and neck injuries was observed in 2011, which may be related to a greater number of injuries to regions of the body that are easily visible to reporting professionals. The increased prevalence may also be attributed to the creation of new reporting units. Veloso et al. (18) reported an increase in the cases of physical violence in 2011, which is the year that two new emergency and urgent care units began notifications.

The most common physical injuries that were reported in 2010 and 2011 were hematoma, which corroborates previous studies $(8,10,17)$. This type of lesion can provide information about time of the incident and the force used by the aggressor in the violent act. Hematomas present chromatic evolution that has been referred to as the Legrand du Saulle ecchymotic spectrum (19). Hematomas are strong indicators of abuse, and professionals can estimate the time of occurrence of the lesion by ascertaining its color. Red or blue bruises indicate occurrence within the past 1-3 days. Greenish yellow indicates occurrence within the past 4-7 days. Yellowish brown indicates occurrence within the past 8-26 days (19).

The prevalence of lesions on the head and neck in 2010 and 2011 was 58\% and 65\%, respectively. Little variation was found in the prevalence of lesions on the head and neck, corroborating previous studies (11). Calvacanti (11) reported that lesions exclusively on the head and face occurred in one-third of child and adolescent victims, 46.4\% of which were on the upper lip. However, the percentage

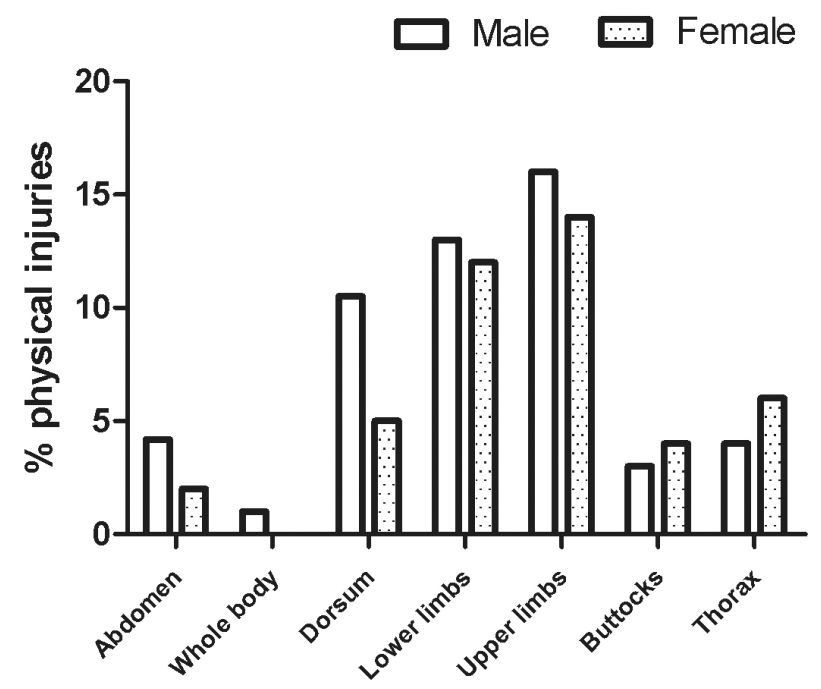

Figure 2. Bodily injuries reported in $2010(n=313)$ according to sex .

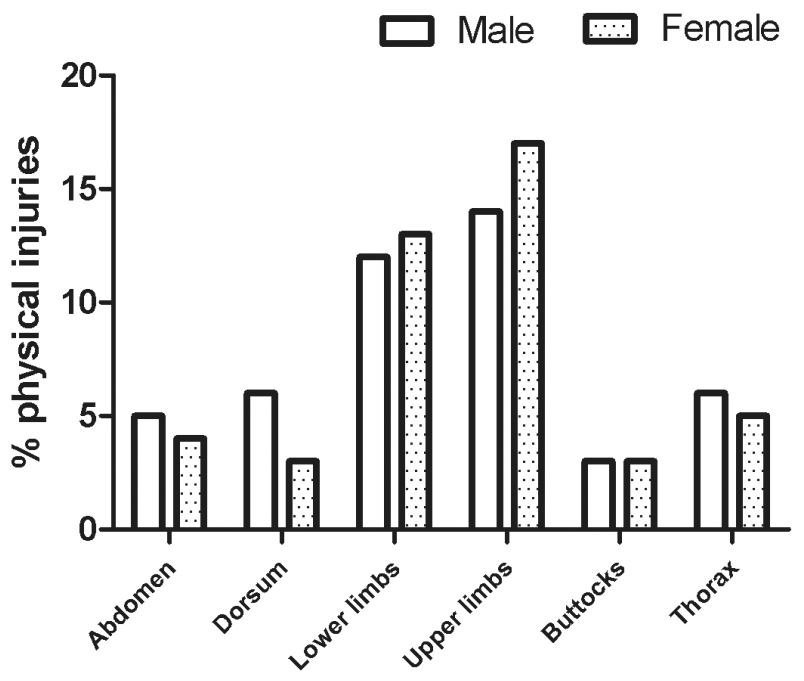

Figure 3. Bodily injuries reported in $2011(n=321)$ according to sex . 
of victims with injuries to head and face, regardless of the presence of other injuries on other parts of the body, was $56.3 \%$. Cairns et al. (6) reported that $59 \%$ of the victims had lesions on the head, face and neck. Jessee (15) found that $66.2 \%$ of the children presented lesions on the head, face, mouth and neck, and $2.6 \%$ had intraoral lesions.

An intraoral examination is essential to rule out or confirm suspicions of abuse. This examination should evaluate soft and hard structures of the mouth (20). Notable in the notifications is the lack of intraoral examinations and in-depth analyses of intraoral lesions, which would allow for an adequate diagnosis of abuse or determination that an accident occurred. Training programs should be offered to health professionals and teachers to provide technical information about such lesions to qualify and standardize examinations of the victims (20). Healthcare professionals, such as physicians, dentists and health technicians should obtain a detailed anamnesis and perform a careful clinical examination to identify whether the lesions were caused by accident or physical violence.

A limitation of the present study was that the notifications were made by health and education professionals who may not be prepared to assess the oral health status of abused children or adolescents. The collected data showed that education units were responsible for $50.6 \%$ of the notifications. This finding shows the importance of preparing all professionals who work with children and adolescents for diagnosing victimized children. One can observe lacerations of the frenulum, tooth fractures, and lesions in the oral cavity related to sexually transmitted diseases caused by sexual abuse $(4,13,21)$. Another limitation is that the notification form does not allow for mouth examinations, which may explain the limited data on injuries in this region.

In the present study, mothers and fathers were the main aggressors of children and adolescents. This result is similar to the findings reported by Cairns et al. (6), in which the mother was the aggressor in $26.7 \%$ of the cases and the father was the aggressor in $25.6 \%$ of the cases. This information is a sad reality because parents should be protectors of their children and not aggressors. Various social factors can influence this behavior in parents, such as drug and alcohol addiction, dysfunctional families, cultural environment and unwanted children (22). Veloso et al. (18) found that the mother was not the main aggressor, but $41 \%$ of the cases consisted of sexual violence, and the reported cases encompassed all ages and all types of violence. Nonetheless, violence against children and adolescents was the most frequent report. There are some possible explanations why mothers are the main aggressor, as the use of violence against the children as a method to educate and to discipline (23). Moreover, some authors showed that subjects exposed to parental violence in the infancy have also performed physical abuse in their kids (14).

Naidoo (17) found that 35\% of aggressors were under the influence of alcohol or other drugs during the act of violence. This problem requires multidisciplinary efforts to fight violence against children and adolescents. Thus, dentists should obtain a detailed anamnesis, perform a careful physical examination, and determine whether the injuries are consistent with the history reported by the child and his or her parents or guardians. In cases of suspected child and adolescent abuse, professionals must notify the authorities to protect this defenseless group.

The present results showed that physical abuse occurs independently of the victim's sex and that parents were the main aggressors. Hematomas were the most frequent injuries, both on head and neck and the whole body. An increase was observed in the prevalence of injuries in these areas in 2011. Given the high prevalence of lesions on head and neck, the health professionals, especially dentists, should look for possible injuries on the head and neck that could be signs of physical violence, in addition to performing routine clinical examinations. A team effort is needed to fight violence and notifications of suspected cases of abuse should be encouraged.

\section{Resumo}

A violência contra crianças e adolescentes é um grave problema mundial e de saúde pública, que ameaça o bem estar físico e mental, deixando sequelas irreparáveis. A notificação desta violência permite sua prevenção e proteção das crianças e adolescentes. Assim, o objetivo desse estudo foi avaliar a prevalência de lesões na região de cabeça e pescoço contra crianças e adolescentes, bem como caracterizar o tipo das lesões, o agressor e unidades notificadoras. Essa pesquisa retrospectiva foi realizada no Centro de Epidemiologia da Prefeitura Municipal de Curitiba. Um total de 10.483 notificações dos anos de 2010 (5.112) e 2011 (5.371) foi analisado, para compor a amostra das lesões físicas ocorridas no ambiente intrafamiliar, na faixa etária de 0 a 17 anos de idade. Em 2010, a frequência de abuso físico intrafamiliar foi de 322 casos. Destas, $57,1 \%$ eram do sexo masculino e $42,9 \%$ do sexo feminino, e $58 \%$ (187) delas tiveram lesões em cabeça e pescoço. No ano de 2011 foram 342 notificações, sendo que $49 \%$ eram do sexo masculino e $51 \%$ do sexo feminino e as lesões em cabeça e pescoço corresponderam a 65\% (222) dos casos notificados. Houve aumento na prevalência de $6 \%$ das lesões físicas e 19\% das lesões na região de cabeça e pescoço, do ano de 2010 para 2011. Conclui-se que é alta a prevalência de lesões na região de cabeça e pescoço, áreas facilmente observadas pelo profissional de saúde e da educação. A criação de órgãos notificadores em hospitais e unidades de saúde é fundamental para a vigilância epidemiológica e para definição de políticas adequadas.

\section{References}

1. Minayo MCS, Souza ER. Violence and health as an interdisciplinary field and collective action. História, Ciência, Saúde 1998;4:513-31.

2. Brazil. Ministry of Health. Available at: http://dtr2004.saude.gov.br/ sinanweb/tabnet/dh?sinannet/violencia/bases/violebrnet.def; Latest access November 12, 2014.

3. Saúde Md. Intrafamilial violence: guidance for practice in public service. Série Cadernos de Atenção Básica 2002;8.

4. American Academy of Pediatrics Committee on Child Abuse and Neglect. Guideline on oral and dental aspects of child abuse and 
neglect. Pediatr Dent 2008;30:86-89.

5. Vieira AR, Modesto A, Abreu VI. Evaluation of the cases of child abuse at Hospital Municipal Souza Aguiar (Rio de Janeiro) and their relationship with the dentist. Ped Atual 1998;11:21-32.

6. Cairns AM, Mok JY, Welbury RR. Injuries to the head, face, mouth and neck in physically abused children in a community setting. Int J Paediatr Dent 2005;15:310-318.

7. Becker DB, Needleman HL, Kotelchuck M. Child abuse and dentistry: orofacial trauma and its recognition by dentists. J Am Dent Assoc 1978;97:24-28.

8. Curitiba. Report of the network for the protection of children and adolescents at risk for violence 2010. Available at: http://www. saude.curitiba.pr.gov.br/images/programas/arquivos/rede_protecao/ RELAT\%C3\%93RIO Rede de Prote\%C3\%A7\%C3\%A3o 2010.pdf; 2010. Latest access November 12, 2014.

9. Apostólico MR, Nóbrega CR, Guedes RN, Fonseca RM, Egry EY. Characteristics of violence against children in a Brazilian capital. Rev Lat Am Enferm 2012;20:266-273.

10. Curitiba. Report of the network for the protection of children and adolescents at risk for violence 2011. http://www.saude.curitiba.pr.gov. br/images/programas/RELAT\%C3\%93RIO vers\%C3\%A3o final 2011. pdf; 2013. Latest access November 12, 2014.

11. Cavalcanti AL. Prevalence and characteristics of injuries to the head and orofacial region in physically abused children and adolescents--a retrospective study in a city of the Northeast of Brazil. Dent Traumatol 2010;26:149-153.

12. Gallo LG. Child abuse: Who is involved? N Y State Dent J 1983;49:7778.

13. Tsang A, Sweet D. Detecting child abuse and neglect--are dentists doing enough? J Can Dent Assoc 1999;65:387-391.

14. Zanoti-Jeronymo DV, Zaleski M, Pinsky I, Caetano R, Figlie NB, Laranjeira R. Prevalence of physical abuse in childhood and exposure to parental violence in a Brazilian sample. Cad Saude Publica 2009:25:2467-2479.

15. Jessee SA. Physical manifestations of child abuse to the head, face and mouth: a hospital survey. ASDC J Dent Child 1995;62:245-249.

16. da Fonseca MA, Feigal RJ, ten Bensel RW. Dental aspects of 1248 cases of child maltreatment on file at a major county hospital. Dent Pediatr 1992;14:152-157.

17. Naidoo $\mathrm{S}$. A profile of the oro-facial injuries in child physical abuse at a children's hospital. Child Abuse Neglect 2000;24:521-534.

18. Veloso MM, Magalhães CM, Dell'Aglio DD, Cabral IR, Gomes MM. Notification of violence as a strategy for health surveillance: profile of a metropolis in Brazil. Cien Saude Colet 2013;18:1263-1272.

19. Resende AJ. Forensic importance of the ecchymotic spectrum - Parte 1. Perícia Médica Legal. http://periciamedicalegal.com.br/?p=6; 2013. Latest access November 12, 2014

20. Maguire S, Hunter B, Hunter L, Sibert JR, Mann M, Kemp AM, et al.. Diagnosing abuse: a systematic review of torn frenum and other intraoral injuries. Arch Dis Child 2007;92:1113-1117.

21. Pinheiro RS, de Franca TR, Rocha B, Ferreira DC, Ribeiro CM, Cavalcanti $\mathrm{SM}$, et al.. Human papillomavirus coinfection in the oral cavity of HIVinfected children. J Clin Pathol 2011 Dec;64:1083-1087.

22. Euser $S$, Alink LR, Pannebakker F, Vogels T, Bakermans-Kranenburg MJ, Van IMH. The prevalence of child maltreatment in the Netherlands across a 5-year period. Child Abuse Negl 2013;37:841-851.

23. Gawryszemski VP, Valencich DMO, Carnevalle CV, Marcopito LF. Child and adolescent abuse in the state of São Paulo, Brazil, 2009. Rev Assoc Med Bras 2012;58:659-665.
Received July 5, 2014 Accepted November 26, 2014 